XVIII.-Excavations on the site of the Roman city at Silchester, Hants, in 1902. $B y$ W. H. ST. John Hope, Esq., M.A.

Read 28th May, 1903.

I HAVE the honour of laying before the Society, on behalf of my colleagues, a report of the operations carried out by the Executive Committee of the Sirchester Excavation Fund during the year 1902, being the thirteenth successive season of the systematic exploration of the site.

The work, which was begun on 15th May and continued without break until 17th November, was carried on throughout under the direction of Mr. Mill Stephenson.

To suit the convenience of the tenant, Mr. Lush, the operations of 1902 were chiefly confined to a narrow and irregularly shaped field of some 4 acres in the south-east quarter of the town, adjoining and lying west and south of the parish churchyard, but we were also able to extend our excavations into the pasture on the west.

The area of the churchyard field in its northern half is a gentle slope southwards, but it then rapidly descends, and its southern end is oniy slightly raised above the level of a small brook which rises in the south-east corner of the pasture.

The first thing undertaken was the laying open again of the long wall running north and south, which was discovered in 1890, and enclosed the two VOL. LVIII. $3 \mathrm{P}$ 


\section{Excavations on the site of the Roman city at Silchester, Hants, in 1902.}

temples partly underlying the churchyard. This served as a limit to our work eastwards and as a base line for the purposes of our plan.

In 1890 this wall was traced southwards until it curved round to the east and passed under the churchyard, where of course it could not be followed (see plan, Plate XXXII.). It was also traced northwards as far as the farm buildings. Last year it happened that the large barn which stands athwart its line was empty, so advantage was taken of the fact to trace the wall to its northern extremity. It was followed right through the barn, and into the modern road crossing the site. It was picked up again on the opposite side, and continued into the field beyond. Here it was found to curve round to the east, as it does at its southern end, but more sharply (see plan, Plate XXVIII.). It will be seen from the town plan $^{\text {a }}$ that it points directly for the southern side of the east gate, and therefore forms the boundary of the main street that traversed the town. This street extended in a straight line from the west gate, past Insulx XI., X., IX., I., XXI., and XXVII., but our discovery of last year suggests that it was then so deflected as to pass out straight through the east gate, at right angles to the section of the wall in which the gate is set.

The insula in which the temples stood has been numbered XXX. Beside the temples, it contained within the rounded north extremity a singular little building (Block I. Plate XXVIII.). This consisted of an oblong chamber, $21 \frac{1}{2}$ feet long and 12 feet wide, with an apse on its broad side towards the west. In continuation of the south end was a sleeper wall extending westwards as far as the enclosure wall. Further to the east are two other walls, also 12 feet apart, running southwards from the enclosing wall, but these apparently belonged to another building (Block II.), and had no connection with the apsidal chamber, which is complete in itself. What was the use of this building it is difficult to say, and nothing was found in or about it to give a clue.

The length of the building (Block II.) to the east of the apsidal chamber could not be ascertained, owing to the walls having been broken away on nearing the fence. The trenches were, however, continued southward, and brought to light another wall running east and west. This returned at its west end, and as will be seen from the plan formed the north side of a building or enclosure (Block III.), the south wall of which was uncovered in the farmyard in 1893."

\footnotetext{
a Fig. 1, at end of Paper.
}

b Archaeologia, liv. 237. 
This enclosure was 43 feet wide, but its east end lies under the road and has not yet been found.

The two temples were fully described in our report for $1890 .^{a}$

The buildings of which traces have been discovered in the field adjoining the church are eleven in number.

The northernmost (House No. 1) was a small house, L-shaped in plan, which abutted on a street or lane 14 feet wide bounding the west side of Insula XXX. The northern wing stood east and west, and consisted of a number of chambers $(\mathrm{A}-\mathrm{E})$ with a corridor $(\mathrm{G}) 9$ feet wide on the south. The western end of the corridor has been cut off to form another chamber ( $F$ ), while its eastern end was expanded to 14 feet in width to form a hall or lobby (H), which probably contained the main entrance. The southern wing, which included this hall, extended southwards from the other along the street and consisted of two chambers (I, J). From its length, 37 feet, the larger of these was most likely subdivided by wooden partitions. The north end of the house was $81 \frac{1}{2}$ feet long, and its frontage to the street 90 feet, but there were some indications of a slight extension northwards. In none of the divisions of the house were any traces of the floors met with.

Immediately to the south of the west end of House No. 1 there were laid bare the traces of a building (Block I.), which may have belonged to it. It consisted of a row of at least three chambers, but the remains were too fragmentary for anything further to be made out. Through the sinking of parts of its floor into a pit we are able to say that the middle chamber had been paved with coarse red mosaic. Near the southern margin of the courtyard between these two buildings was a well (c) 18 feet deep, with a wooden tub at the bottom as a lining.

To the west of Block I. and parallel with it at a distance of about 10 feet were the gravel foundations of an oblong enclosure or building (Block II.), standing north and south, measuring internally 44 feet by 16 feet. Nothing was found in or about it to suggest its use or how it was paved.

The three buildings just described seem to have stood on the north side of a street running east and west, and extending from the wall of the temple enclosure to the chief entrance into the forum. The northern limit of the insula in which the buildings stood has not yet been fixed, but we have numbered it XXIX.

a Archaeologia, lii. 745-749.

3 Р 2 


\section{Excavations on the site of the Roman city at Silchester, Hants, in 1902.}

The insula to the south (No. XXXI.) is also at present only partly explored, but we have uncovered at least two buildings in it.

The largest of these stood immediately south of Block II. (Insula XXIX.), and was a house (House No. 1) with its north front along the street, which was here 18 feet wide.

The house consisted of a northern and a southern wing, at right angles to each other. (See plan, Plate XXVIII.) The northern wing primarily consisted of two large rooms $(A, C)$, with an intervening passage (B), and flanked on each side by a corridor. As was so often the case the west corridor has been subdivided (D, E), and its north end finally replaced by a larger room (F), with a latrine $(G)$ on the west. The north end of the eastern corridor (H) has been similarly encroached upon by a winter room (J) and ante-room (I) extending eastwards from chamber (A).

The position of the ante-room with regard to the rest of the house suggests that the main entrance from the street opened into it, but the difficult point to understand is how it could serve even as an ante-room, when it also contained the stokehole of the hypocaust of the winter room (J) adjoining. This hypocaust was of the usual channelled variety and supported a floor of opus signinum, part of which remained in place. The doorway of this winter room must have been in the north-west corner, opposite another doorway from the ante-room into chamber A.

The southern wing of the house stands east and west, with the main corridor (н) returned along its north side. It only partly overlapped the other part of the house, and consisted of two large rooms ( $\mathrm{K}, \mathrm{L}$ ), each originally furnished with a hypocaust, worked from a stokehole at the east end of the range. At some later period in the existence of the house, perhaps after the northern winter room was built, both hypocausts were completely cleared away, and the rooms put to other uses. The westernmost (K) was partly occupied by a large boiling furnace, consisting of a rectangular chamber, apparently fitted with square pilæ to support the vat or copper, and heated from a long brick flue or stokehole on the east (Plate XXIX.). The apparently additional flues at the sides were perhaps only the supports for a vessel of greater width than the furnace chamber. What may have been a woodshed (M) stood a little to the east of the rooms just noticed, at the end of a continuation of the north wall of the corridor. A little further east was a wood-lined well (D), 17 feet deep.

Some little distance to the south of the house just described were the scanty 


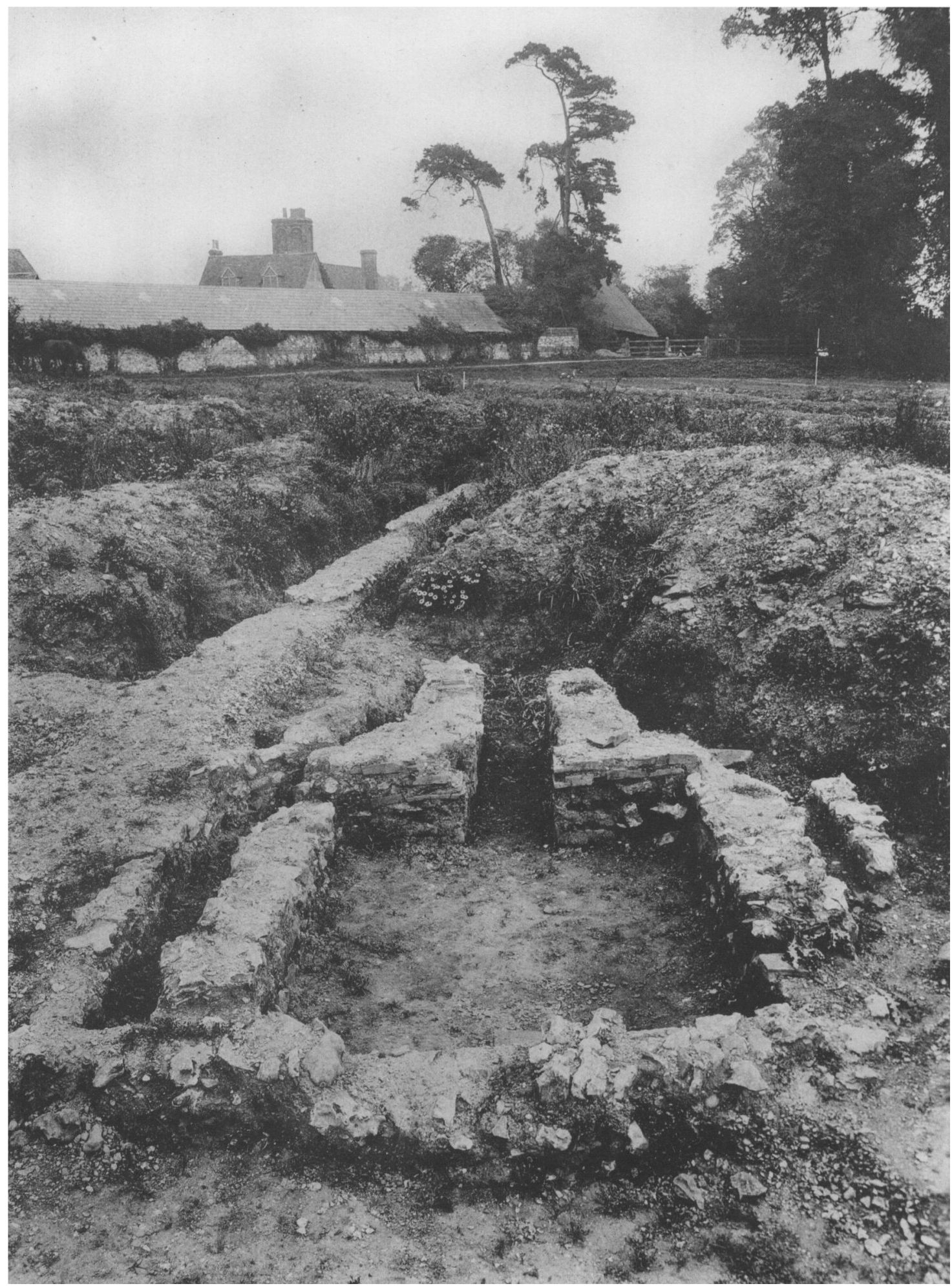

SILCHESTER.-FURNACE IN HOUSE No. 1. INSULA XXXI.

Published by the Society of Antiquaries of London, 1903. 
traces of another (? House No. 2). These traces include the remains of a winter room warmed by a pillared hypocaust, and part of a range of chambers to the east with a return southwards. Close to the north-east corner of these remains was a wood-lined well (в), 18 feet deep. There are some reasons for assuming that immediately to the south of the building just described there lay another street, running east and west past the southern border of Insula XXX. No positive traces of it beyond a bed of gravel were found, but the arrangement of the building next to be described is very suggestive of it.

This building, which may be called House No. 1 of Insula XXXII., consisted of a fairly symmetrical block, standing north and south (see plan, Plate XXXII.); but the north end, that towards the street, forms a slight angle with the rest of the house, and has apparently been rebuilt. It seems, then, that we have here another instance of a house that was erected before the town was finally laid out, and had to be altered to suit the new lines of roadway. Owing to the position of this house on the edge of a slope its northern end was built into the hill, and was found standing to a height of about $3 \frac{1}{2}$ feet. For the same reason it was built of greater thickness than usual. The house consisted of a central range of chambers $(A, B)$ between a narrow corridor (c) on the east and a wider one (D, E), which was subdivided, on the west. The subdividing walls are so few that the other divisions must have been wooden partitions. That wood was actually used in the construction of the building, probably in all of it from a few feet above ground, is shown in an interesting way by the socket or bed of a longitudinal beam in the north wall of the western division of the house. (Plate XXX.) The room (D) of which this wall forms the north end presented other features of interest. Built into its east side was a block of brickwork with the remains of a hearth against it, as if for an internal fireplace. Imbedded in the ground at the south end of the room were four earthenware pots, one of which was covered with an octagonal tile, and another with a thin piece of stone. Pots similarly placed have been found in other houses at Silchester, but their object is still a matter of dispute. To the south of the room under notice a quantity of loose red tesseræ was found, and these are the only indications as to how any part of the house was paved. Mr. Lyell has called my attention to the large amount of charcoal overlying the interior of this house at the floor level. Seeing that so much of the construction was wood, it is possible that the building was destroyed by fire.

A short distance to the east of this house were laid open the remains of another (House No. 2) of about the same size, and not unlike it in plan. 
Archaeologia.

VOL. LVIII. PL. XXX.

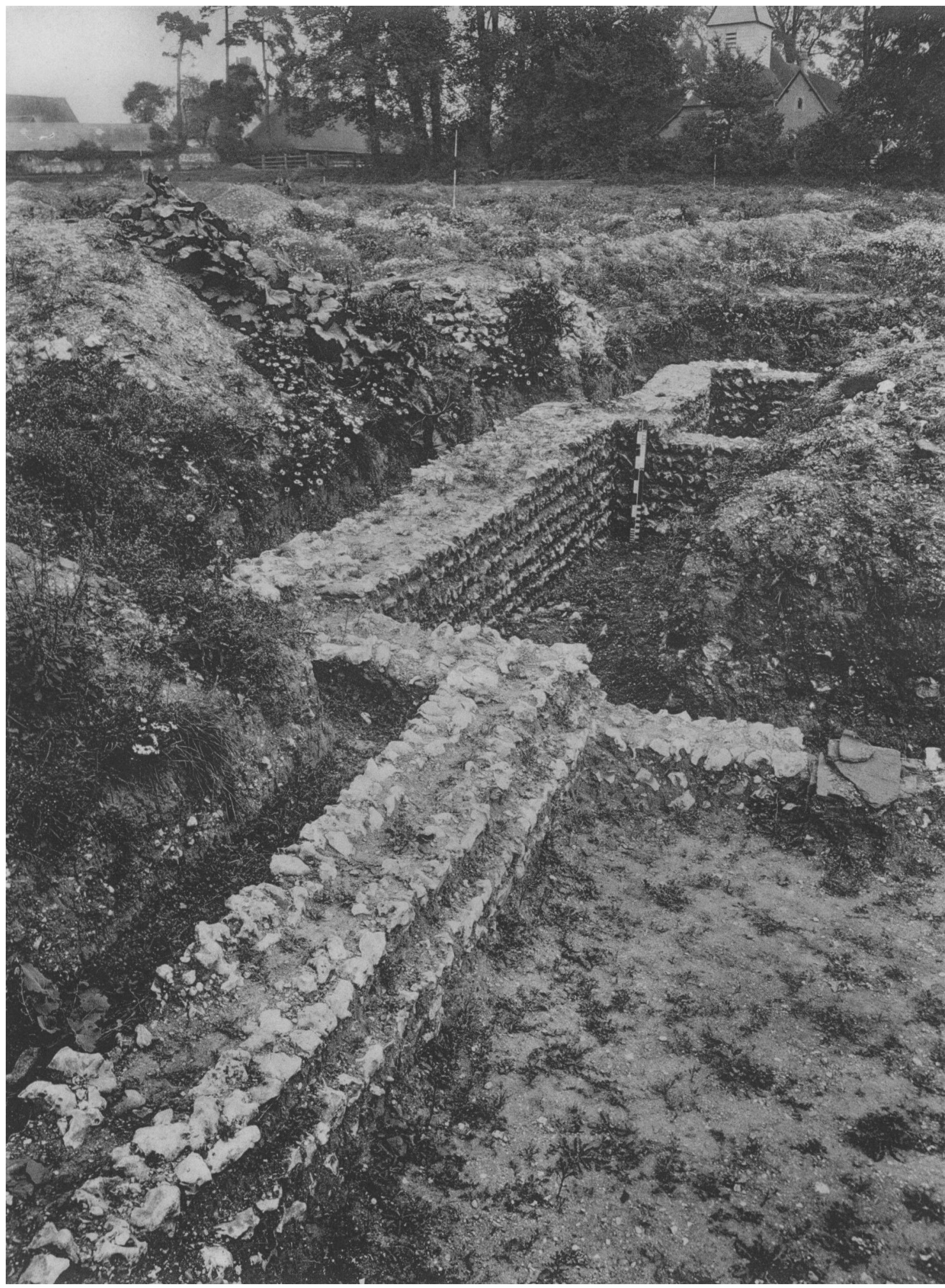

SILCHESTER. -WALL WITH SOCKET FOR BEAM IN HOUSE No. 1. INSUTA XXXII.

Published by the Society of Antiquaries of London, 1903. 
It consisted of a central row of chambers $(A, B)$ with a narrow corridor (C) on the west, and a wider one (D) on the east, with a transverse row of two chambers $(\mathrm{E}, \mathrm{F})$ on the south. The corridor (C) was apparently little else than a wooden pentice, but there is of course nothing to show how far it was closed against the weather. At its north end are the remains of a return passage (G) running westwards. The central row of chambers was probably further subdivided than by the cross wall found by timber partitions. Of the eastern adjunct (D) nothing could be traced except a patch of coarse red tessellation at its southern end. The room (E) south of it presented nothing remarkable, but the large winter room ( $F$ ) that completed this end of the house exhibited several features of interest. First its size should be noticed, it being 27 feet long and 20 feet wide. The hypocaust that warmed it was of the composite class, with an oblong chamber in the middle filled with octagonal pilix, and radiating flues to the corners and side walls. (Plate XXXI.) The pila were twenty-four in number, in four rows of six each, and unusually close together. The fact of their being built up of octagonal tiles is noteworthy, for though tiles of this shape have repeatedly turned up singly, they have only rarely been found at Silchester forming pilx. The hypocaust was worked by a stokehole on its north side, in the southernmost of the main row of chambers. From the remains of older foundations which traverse the hypocaust, it is evident that the southern part of the house consisted originally of three chambers of nearly equal dimensions, but the two westernmost were eventually thrōm into one and converted into a winter room warmed by the hypocaust. Between the two houses just described and about equi-distance from both, there was uncovered a somewhat irregular patch of coarse red tessellation (Block I.). Closer examination showed that it had apparently formed the floor of a wooden building about 11 feet square, subdivided by a partition 8 inches thick. It is rather too far from House No. 2 to have ever formed part of it, though the close coincidence of its main lines of direction with those of the house suggest that it was connected with it in some way, despite the absence of any traces of such connection.

Immediately to the east of House No. 2 are the foundations of two buildings, the like of which have not occurred before at Silchester. That to the north (Block II.) was a long and narrow structure, measuring internally 58 feet by 6 feet, and built across the slope of the hill so as to maintain a fairly level floor. The west side and the two ends were only 15 inches thick and for the most part built of tiles, but the east side formed an open arcade or portico of six bays. Of the 


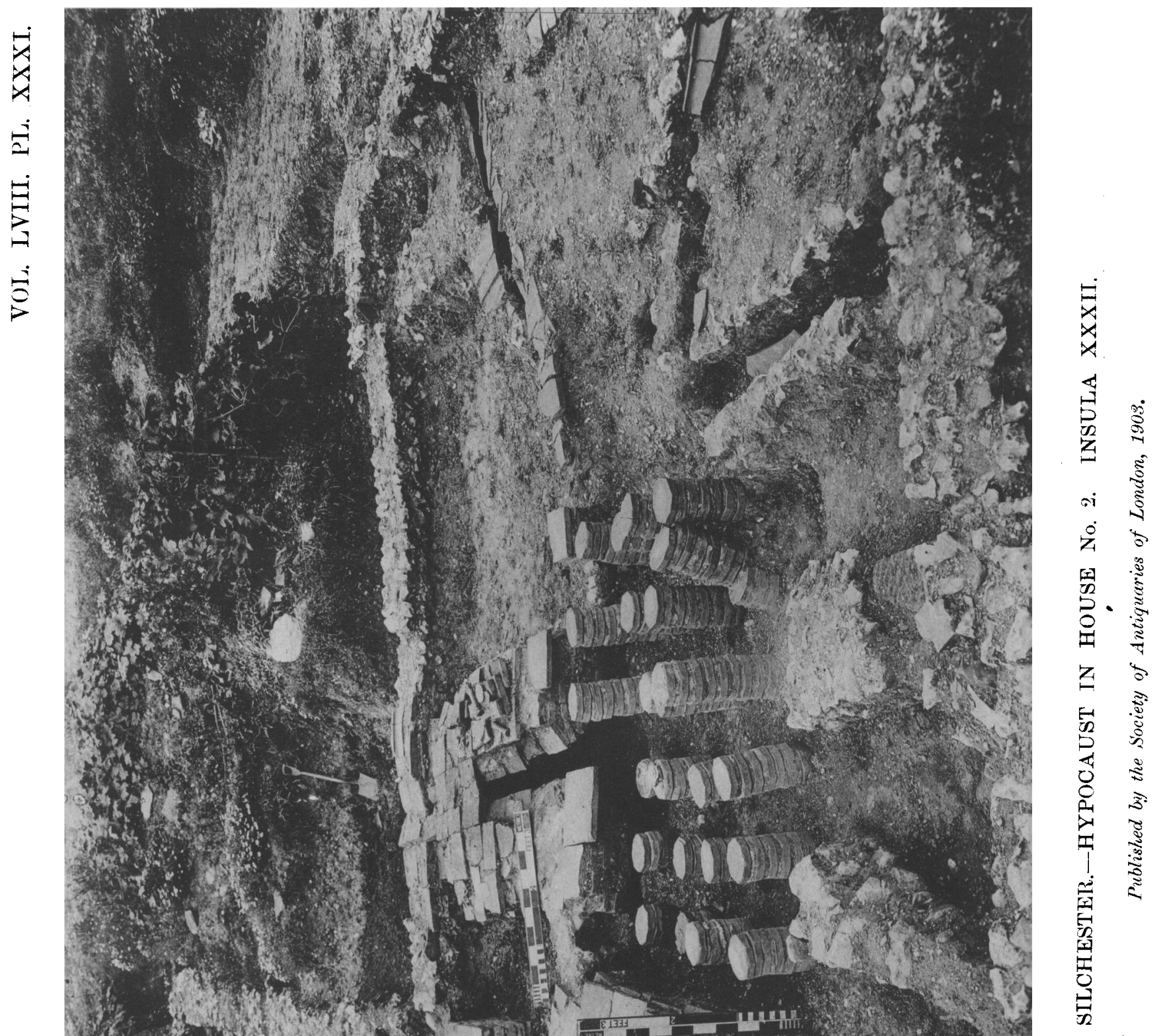


character of this portico we have no evidence, inasmuch as only the bases of the supports remained, and these were merely oblong masses of tile; we are also equally in the dark as to the use to which the building was put. Nothing of its floor remained and nothing was found in or about it.

The other building (Block III.) was of totally different plan and character. It consisted of a semicircular wall of flint rubble, with an internal diameter of 15 feet, with a short return on either side along the diameter, as if the open side, which faced up the slope towards the north-east, were partly closed by an arch so as to form a kind of alcove.

From the fact that both buildings face uphill and turn their backs upon House No. 2, it looks as if they stood in the grounds of House No. 3, which was excavated in $1896,{ }^{a}$ and now underlies the recent extension of the parish churchyard.

A wood-lined well (A) 17 feet deep to the west of Block III. probably belonged to House No. 2.

South of the buildings described our trenches did not reveal any further foundations, and owing to the lowness of this part of the site it was probably open or garden ground.

The little stream which served as the western boundary of our season's work now passes out of the town through a breach in the wall. As, however, there could have been no such breach here originally, the sides of it were examined in the bope of bringing to light the remains of an archway or some such proper outlet. But the result was only partly successful, for although we found on the east side remains of the vertical jamb of an opening, on the west it had been destroyed, and what was left on the east did not extend high enough to show traces of an arch. We were able, however, to determine that this section of the wall, like that to the west, which also traverses low marshy ground, was built upon piles, and at the base of the opening through the wall there was laid across it a stout baulk of oak about 9 inches square, perhaps part of a sluice gate.

About 100 feet to the east of the breach through which the brook flows out, the line of the town wall, which here bounds the site, makes a small angle. As these angles are usually marked by one of the inner buttress-like projections which we think formed the bases of towers set at intervals astride the wall, search was made for one at this point. The result was satisfactory, inasmuch as

archaeologia, 1v. 428, 429. 
both the turret base and the external plinth with part of the facing of the wall were found, but the turret itself had been displaced over 3 feet outwards by a settlement, and the wall adjoining it on the west was also forced out of line by the growth of a huge tree. Another turret was disclosed about 200 feet to the north when the brushwood was cleared from the face of the portion of the wall that bounded the extension of the churchyard.

The excavations in the pasture to the east of the churchyard field were of a somewhat limited character. An area of about $\frac{5}{6}$ acre occupying the north-east corner was enclosed by hurdles, and the ground trenched in the usual way. We first brought to light the foundations of a small building (Block III.); it stood east and west on the edge of the street bounding Insula XXIX. on the south, and consisted at first of two small rooms, to which a third had been added later at the east end. These perhaps formed a row of shops.

A little to the north were the remains of two floors of coarse mosaic, the one white, the other black, divided by an interval of two feet and forming roughly a square of 18 feet (Block IV.). There were no remains of walls, and we can therefore only assume that the building to which the floors belonged was entirely of wooden construction. The white pavement, which was the southernmost, was about $6 \frac{1}{2}$ feet wide, but the black floor had a breadth of 10 feet. Against the northern margin of the block were the well-preserved remains of one of the usual long flues or hearths.

Both the structures just described clearly formed part of Insula XXIX., and were apparently separated by a narrow line or street from other remains further west.

These remains occupied most of the western side of our working area, and consisted of two houses, bordering on and extending northwards from the street on the south. As will be seen from the general plan, ${ }^{a}$ they form part of Insula XXVII., the northern margin of which was excavated in 1901.

House No. 1, which is unquestionably the earlier, consisted originally of a series of six chambers or divisons, forming a block about 80 feet long, standing east and west, with a corridor on the south. Nothing was found to show how the different parts of the house had been floored. The house stood back from the later line of street, and not quite parallel with it, and probably had an upper story. There was subsequently added to it a large winter room

a Fig. 1, at end of Paper. 
projecting southwards from the middle of the corridor as far as the street, with which it was also built at right angles. The stokehole of the hypocaust was in the corridor, an arrangement which is somewhat unusual, but it was found in two other of the houses uncovered in 1902. At a later period the house seems to have been pulled down, with the exception of the winter room, and perhaps part of the adjoining corridor. The hypocaust was cleared away, and its area converted into a dyer's workshop, as is shown by the remains of one of the long flues which has been built within it. To the same date as these alterations we may perhaps assign the square chamber which has been built upon the foundations of the westernmost room of the destroyed house.

Some 27 feet north of the north-east corner of the house was a wood-lined well (E), 8 feet deep.

House No. 2 may be claimed as belonging to the courtyard type; the two divisions or wings of which it consisted being placed at right angles on two sides of a court. The one wing of the house extends along the west side of the court, and consisted of a chamber (A), perhaps a porter's lodge, some 15 feet square, with a corridor (B C) running northwards from it. This corridor seems to have been of more than one date, and was apparently subdivided into several small rooms. The other wing of the house extends along and beyond the north end of the court, and consisted of a row of five chambers or divisions (D- $\mathrm{H}$ ), one of which may have contained a staircase to an upper floor. There were no definite remains of any corridor communicating with these chambers, but the whole of the foundations were very poorly preserved. The courtyard had been subdivided by a wall into a larger outer and a smaller inner court. In the former was a wood-lined well (F), 10 feet deep. On the south the court was closed towards the street by a wall, which also extended as far as the added chamber of House No. 1. From the west side of House No. 2 here extends northward a wall of earlier date, which was followed up to the hedge of the present roadway. It is so nearly in line with the return angle of a building excavated in 1901, on the other side of the road, that they even probably connected, but owing to the fragmentary nature of the northern end this cannot be proved.

It will be seen from the town plan ${ }^{2}$ that the excavations of 1902 have

a Fig. 1, at end of Paper.

VOL. LVIII.

$3 \mathrm{Q}$ 
added materially to our knowledge. The six complete houses uncovered are all of interest on account of their small size, and of the other five buildings two at any rate are of a new type. It is unfortunate that the topographical limits to the excavations compelled us to deal with parts only of insulæ, but we hope to be able to complete some of them during the forthcoming season.

The circumscribed area of last year's operations had a further unfortunate result, that the comparatively small amount of open ground between the buildings contained but few pits or wells. The miscellaneous antiquities found are consequently so few in number that the Committee has not thought it worth while this year to lave an exhibition of them.

But few traces were met with of mosaic pavements, and those even of the coarsest description only. The few pieces of painted wall-plaster also do not call for remark.

Used up as building material in the large hypocaust of House No. 2 in Insula XXXII. was a fragment of an inscription. It was cut on a slab of sandstone at least 6 inches thick, and the letters were 5 inches high and of good early character. An $\mathbf{A}$ in one line and in the next the letters $M F$ are all that remain, and these are imperfect. The complete inscription may originally have formed part of one of the adjacent temples. If so, it would point to the destruction or rebuilding of the temple before the erection of the house in question.

Close to House No. 1, Insula XXXII., was found a fragment of an Attic base of good character, with part of an attached shaft, which must have been about $8 \frac{1}{2}$ inches in diameter. Possibly this, too, came from one or other of the temples. The same remark applies to some portions of Purbeck marble mouldings and wall linings.

Of the other objects discovered the most noteworthy is the half of an upper quernstone of Andernach lava. Its diameter was 28 inches, and there still remain in the upper surface the iron staples of the handles by which it was worked.

The bronze objects include two good brooches, a toy axe, a bell, a curious torque of debased silver, and a number of needles and pins. Another pin is of silver, as is also a plain ring with traces of gilding.

Among other metallic objects are a rod of solder, a three-legged candlestick of iron, and a few keys, etc. of the same metal. 


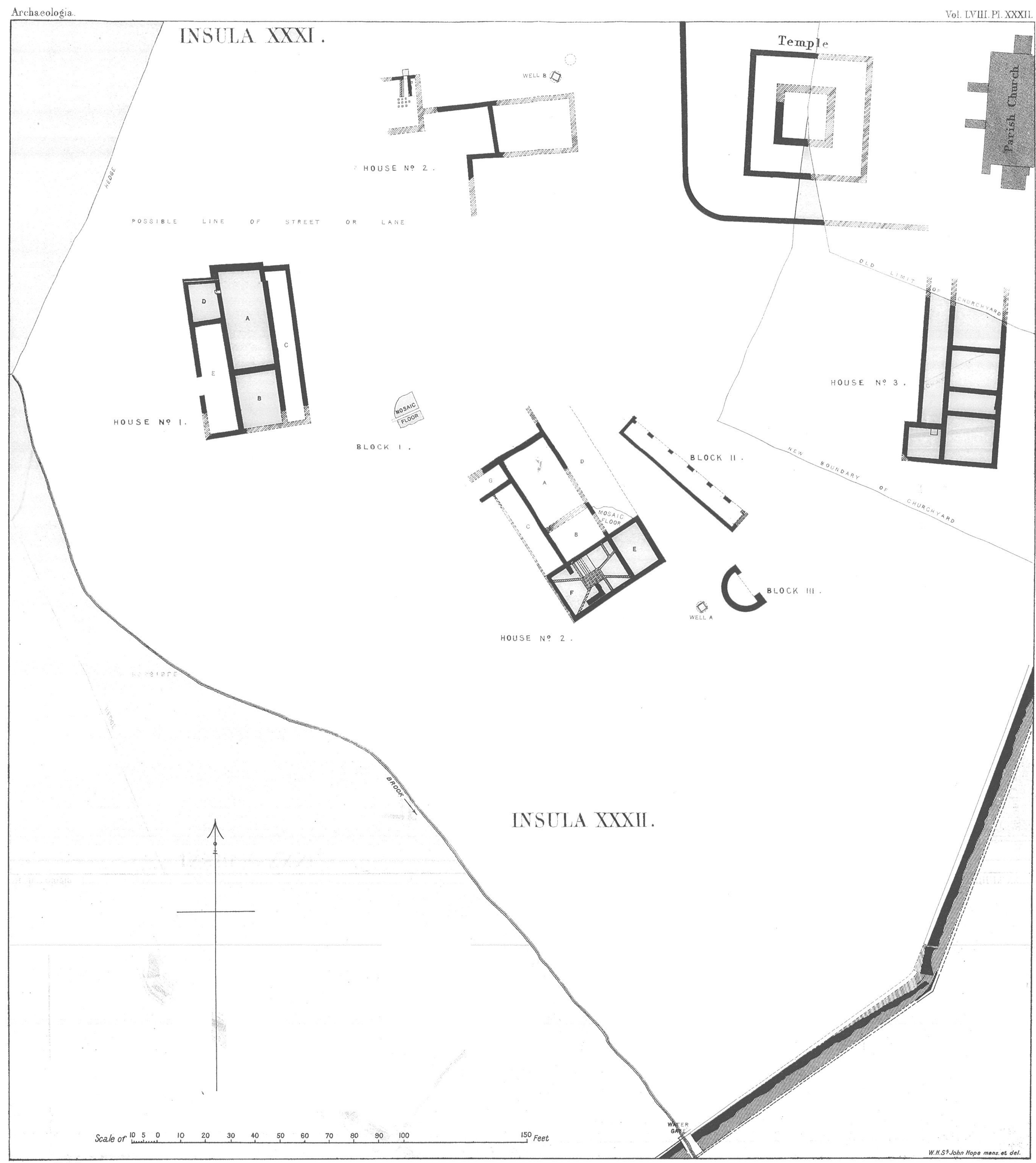

SILCHESTER-- SOUTHERN PART OF AREA EXCAVATED IN 1902. 
Excavations on the site of the Roman city at Silchester, Hants, in 1902.

The objects in bone consist almost entirely of the usual assortment of pins and needles and small flat counters.

Of shale there are parts of two large trenchers and some fragments of bracelets.

The fragments of glass do not call for remark.

The amount of pottery found was insignificant when compared with the large number of vessels recovered in other years. A mutilated figure of Venus, modelled in pipeclay, was found in Pit V. at a depth of 4 feet.

Among the very few extraneous objects are a polished stone axe of the Neolithic period and an iron rowel spur of the time of the Civil War.

Coins were fairly numerous.

Of the wells, that marked A, in Insula XXXII., close to Block III., was 17 feet deep, and was lined for 11 feet from the bottom with oak boarding, forming a framework 3 feet square. The boards, of which there were seven rows, varied in width from 13 to 20 inches. Among other things found in this well was a fine specimen of a horse's skull, at a depth of 12 feet, skulls of sheep and oxen, a vessel of red-glazed ware, and a black pot.

Well B, in Insula XXXI., north of House No. 2, also had a wooden lining 2 feet 6 inches square, extending for $8 \frac{1}{2}$ feet up. The boards of this were about a foot broad, and have been pronounced by Mr. Clement Reid to be of alder. A small wooden bucket, with iron handle and two bands of the same material, was found at the bottom, and also the handle of another bucket.

Well C, in Insula XXIX., close to the street, was lined with a wooden barrel 3 feet in diameter, formed of 19 staves, but it was in a very decayed condition.

Well D, in Insula XXXI., near House No. 1, was 17 feet deep, with a timber framing 3 feet square for 10 feet up. The boards were of oak. A mong the finds were a jug of pottery, and a copper coin of Caraucius (?) which was wedged in between two of the boards of the lining.

Well $\mathrm{E}$, in the pasture, was only 8 feet deep, and lined to half-way up with a wooden framing 3 feet square. It contained much broken pottery.

Well F, also in the pasture, in the courtyard of House No. 2, was 10 feet deep, with a wood lining $2 \frac{1}{2}$ feet square.

The numerous bones found in the wells and pits have been examined by Mr. E. T. Newton, who has kindly submitted the following note upon them:

"Many mammalian and other bones have been found during the Silchester 3 Q 2 
explorations of 1902. The greater number of these remains belong to Oxen, and most of them, including a portion of a skull and several lower jaws, together with limb-bones, are parts of animals of moderate size, which cannot be distinguished from some of our modern cattle (Bos taurus). There are, however, a few bones, including a frontal with horn-cores attached, which are referable to the long-faced Ox (Bos taurus, var. longifrons).

The Horse (Equus caballus) is represented by a skull and lower jaw ramus, evidently belonging to a fair-sized horse; certain limb-bones, however, are parts of a much smaller animal.

The Sheep (Ovis aries).-A nearly complete skull and half another, together with a lower jaw ramus, agree with similar parts of modern sheep; some limb-bones may likewise belong to sheep, but may possibly be parts of a goat.

The Goat (Capra hircus). - Some horn-cores and a piece of a young jaw with milk-teeth clearly belong to this species, and certain of the small ruminant limb-bones may be referable to this species.

The Red-deer (Cervus elaphus).-A few pieces of antlers represent this animal; one of these retaining the "burr" is part of a shed antler; other pieces are interesting on account of their having been sawn across.

The Roe-buck (Capreolus capræa).-A well-preserved metatarsal bone is the only part of this animal yet found.

The Pig (Sus scrofa).-A piece of a lower jaw and two fibulæ are referable to this species; as well as a large tusk apparently belonging to a Wild Boar.

The Dog (Canis familiaris).-Two or three skulls and a number of limbbones indicate the presence of at least three different kinds of dogs, ranging in size from a terrier to a stag-hound. One ulna found in the floor of a house is much bent, and must have belonged to a bow-legged animal, suggesting the form of some bull-dogs or perhaps an otter-dog.

The smaller mammals are represented by a few bones of the Field-mouse (Mus sylvaticus), the Field-vole (Microtus agrestis), the Bank-vole (Evotomys glareolus) and the Shrew (Sorex vulgaris).

Very few birds' bones have been found this year; there are some, however, belonging to a small fowl, about the size of a game bird, and the strong spur upon one metatarsal bone seems to favour this idea. Bones of a Wild-goose (Anser 
cinerius?) and a few of those of a Woodcock (Scolopax rusticula) are also among the scanty avian remains obtained during the 1902 explorations.

The only Fish that we were able to record for 1901 was the Eel; but this year we have evidence of three other fishes as well as the Eel.

The freshwater Stickleback (Gasterosteus aculeatus) is represented by two of the characteristic ventral spines and one of the ornamented pelvic bones. The recovery of these minute specimens bears testimony to the care with which Mr. Lyell has searched for the smaller organisms. The other two fishes are marine forms, a Sea Bream, several scales of which have been found at a depth of about eight feet from the Roman surface, and a Herring (probably Clupea harengus), a small but characteristic bone of the skull having been preserved.

The presence of these remains of marine fishes so far from the sea coast opens up some interesting questions. May it be taken for granted that they had been used as food? The possibility of their having been brought by birds at once occurs to our minds. But the Sea Bream scales were found in "Well C," and this seems to indicate that they were domestic refuse, and most likely therefore had been used as human food. The fragment of Herring also was found, with a few remains of Eels, Mice, and Birds, in a small and irregular hole under the foundation of a house in the grass field, and may therefore have been part of a refuse heap subsequently built over."

The search for remains of plants, etc. in the filling in of the wells and pits has again been followed up with exemplary care and patience by Mr. A. H. Lyell, and the results have been examined by Mr. Clement Reid, F.R.S., who has most kindly furnished us with the following report:

“The material collected during 1902 by Mr. A. H. Lyell from the rubbish pits and old wells has proved of more botanical interest than that obtained in 1901. It has yielded seeds of various plants for which the mediæval herbals were till now the earliest records. Most of these additions to the flora of Roman Britain are well-known weeds of cultivation, which may have been introduced in Roman times, or may date back to the first introduction of cereals and vegetables during the Bronze and Neolithic periods. At present scarcely any material undoubtedly belonging to these two periods has been examined for plants, and the species known are very few; but ultimately 
we shall be able to fix the date of the introduction of our various cultivated plants and weeds of cultivation, and then we can use seeds, as we do coins or pottery, for fixing the date of ruins or camps of unknown age. Before this can be done it is necessary, however, that we should obtain a good knowledge of the flora of each successive period, from material collected and dated in the same careful way that the Roman material is now being gathered up and preserved by the Silchester Committee.

The additions to the flora of Roman Silchester obtained last season are twenty-four in number, besides seeds of several plants not yet determined:

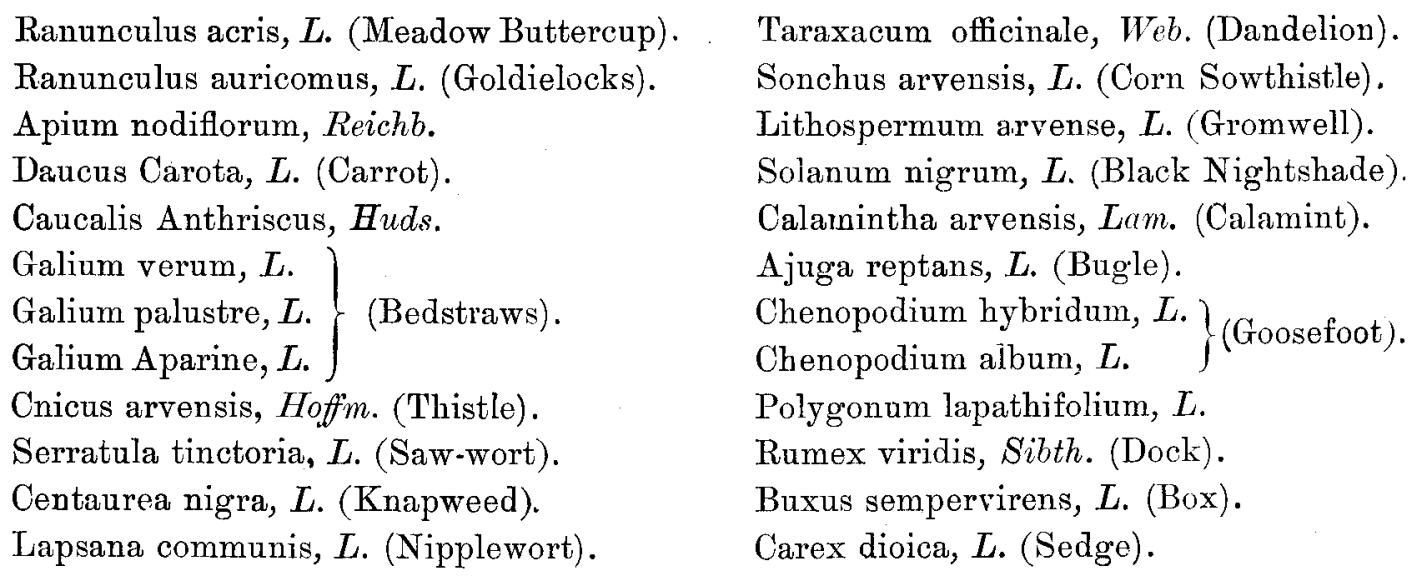

One of these plants is of considerable interest, for it throws light on a question that has much exercised the botanist. The box tree is of such partial occurrence in Britain, being only found wild in a few localities in the south, that it has always been a matter of doubt whether the tree could be considered native. If not native, at what date was it introduced? Box-clippings have now been found in Pit XIII. (1902), and this shows that the tree certainly grew in Britain as far back as Roman times. But whether the box was indigenous or cultivated at Silchester there is nothing definite to show, for it occurs as clippings only. The fashion of clipping the box into fantastic shapes was well known in Roman times, such trees being among the adornments of Pliny's villa at Tusculum. At Silchester, however, the box clippings are associated with various weeds and the untidy elder, not with either garden plants or shade trees. This perhaps suggests that the clippings belonged to withered garlands made from wild trees, and were not gardener's waste. 
The discovery of seeds of fig and grape in several fresh pits makes it increasingly probable that they were cultivated in Britain, and were not the mere remains of imported dried fruits. Neither the fig nor the vine is difficult to cultivate in the south of England, and the non-occurrence of other dry fruits, such as the almond, which do not ripen in Britain, suggests that only home-grown fruits were obtainable. If the wood of the fig and vine should turn up, it will settle the question, for neither of these woods is of any value, and they would not be imported. The occurrence of masses of grape seeds and skins, such as would form the refuse of a wine-press, would be conclusive; but at present the seeds occur sparingly, suggesting grapes or raisins for eating, not for wine. The question is a difficult one, for on the one hand we find imported wine-casks made of silver-fir and strongly suggesting a trade with Bordeaux; on the other we find seeds of grape, suggesting that the vine was grown in Britain.

In a former report I pointed to the extraordinary abundance of seeds of poisonous plants in the old wells in Silchester as a suspicious circumstance. It now appears to be perfectly explicable without casting any slur on the inhabitants. Berries of Atropa Belladonna were freely used as a cosmetic; hence the constant occurrence of seeds of the deadly nightshade in the house-refuse. In all probability this exceedingly dangerous plant was not allowed to grow in the town, or within reach of children or cattle; but was brought from a distance. The woody nightshade and black nightshade are both plants of common occurrence in gravelly wastes and among old buildings; their occurrence, associated with the elder, overhanging dilapidated wells, is not surprising. The other poisonous plant, the hemlock, grows and seeds so freely among the tall sedges used for thatching, that it wonld be surprising if a good many seeds of it were not entangled in the thatch.

A comparison of the cultivated plants with those grown in Italy raises various questions which at present we cannot answer. The pear, the peach, the apricot, and the chestnut are all missing, and the plums do not belong to the numerous good varieties known to the Romans. The grape and fig are the only fruits which they seem to have introduced into Britain. It is curious to find in a collection of seeds from the Roman layer in Tooley Street, recently sent to me by Mr. Kennard, exactly the same association. There also the fig and grape occur with no better fruit than the damson, and are associated with the same weeds of cultivation. In each locality there is the same singular absence of some of our commonest weeds, such as the groundsel, the daisy, and the white dead-nettle. It would now be 
interesting to examine the plants from a wealthy and fashionable town like Roman Bath, for there if anywhere we might expect to find the fruit eaten by the rich."

With these interesting remarks of Mr. Clement Reid our report may fitly conclude.

The accompanying block-plan (fig. 1) shows the progress made in the excavation of the site.

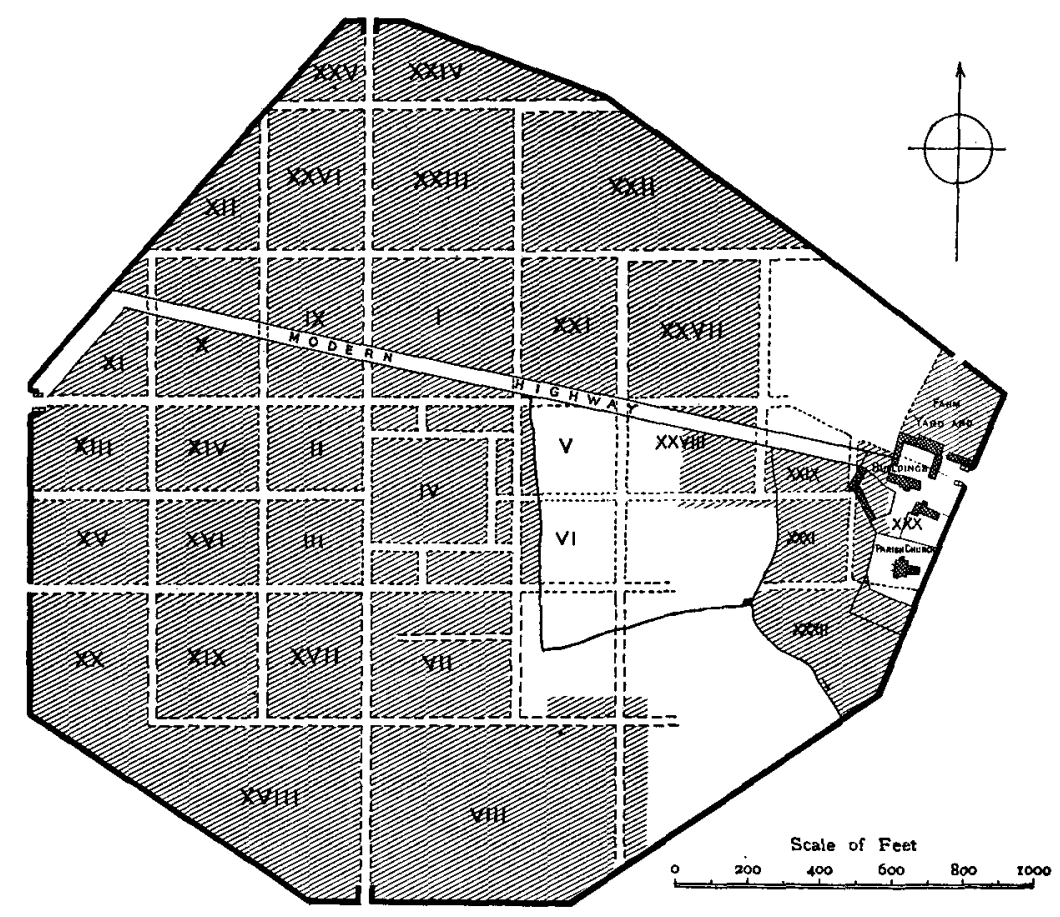

Fig. 1. Block-plan of Silchester, showing portions excavated down t, the end of 1902. 